Article

\title{
Field Population Density Effects on Field Yield and Morphological Characteristics of Maize
}

\author{
Vasileios Greveniotis ${ }^{1,2}, *$, Stylianos Zotis ${ }^{2,+}$, Evangelia Sioki ${ }^{3}$ and Constantinos Ipsilandis ${ }^{2}$ \\ 1 Department of Agricultural Technology, Technological Educational Institution of Thessaly, \\ 41110 Larissa, Greece \\ 2 Department of Agricultural Technology, Technological Educational Institution of Western Macedonia, \\ Terma Kontopoulou, 53100 Florina, Greece \\ 3 Department of Agricultural Economics, Aristotle University of Thessaloniki, 54124 Thessaloniki, Greece \\ * Correspondence: vgreveni@teilar.gr; Tel.: +30-241-068-4365 \\ + Late author.
}

Received: 23 May 2019; Accepted: 19 July 2019; Published: 21 July 2019

\begin{abstract}
The objective of this study was to evaluate the effect of population density and row spacing on field yield and other morphological characteristics of two commercial F1 maize hybrids of different biological cycle (Costanza and LG3535) in a four-year period. Field experiments were conducted in a split-split plot design, in two population densities and three types of row spacing, involving single or twin rows. Ten plants from each plot were selected randomly and plant height, ear emergence height, ear length, ear diameter, number of grain rows per ear, grains number per ear, grain weight per ear, spindle weight per ear, and spindle diameter were measured. Grain yield of each plot was measured and field yield, thousand kernel weight and bulk density were calculated. Four years of experimentation clarified that environmental conditions may distort all other effects of the factors studied. This study points out the best combination of plant density and row configuration. High populations and twin or narrow rows $(50 \mathrm{~cm})$ were found to be important for maximizing yield of modern maize hybrids. Differences between hybrids were not significant, although Costanza exhibited greater mean field yield performance $(14,364 \mathrm{~kg} / \mathrm{ha})$. Plant density was a significant factor and yield was increasing from low to high plant population (from 13,900 to $14,527 \mathrm{~kg} / \mathrm{ha}$ ). Plant density and genetic materials affected thousand kernel weights that showed the highest value at low plant density (364 g). Row spacing showed a significant interaction with year. Generally, twin or narrow rows favored many characteristics, especially height characteristics. Plant height reached $320 \mathrm{~cm}$ and ear height reached $149 \mathrm{~cm}$. Ear diameter was favored by low plant density. Some ear characteristics were found to be depended on the genotype behavior in the certain environmental conditions. For spindle weight per ear, a total interaction between years, row spacing, hybrids, and plant density was found. For spindle diameter, various significant interactions were found, including years (maximum also in 2009), row spacing, and plant density and also row spacing, hybrids, and plant density. Many correlations were found significant especially between yield and thousand kernel weight, spindle weight per ear, and ear diameter that may prove to be useful for plant breeders.
\end{abstract}

Keywords: Zea mays L.; hybrids; spacing; field yield; maize characteristics

\section{Introduction}

The introduction in cultivation of single maize (Zea mays L.) hybrids and improved techniques of cultivation led to a spectacular increase in yields over the last 40 years. Duvick [1] stated that increased field grain yield of modern hybrids is a result of improved tolerance in abiotic and biotic stresses, 
accompanied by maximized yield per plant under nonstress growing conditions. Later, Duvick [2] stated that modern hybrids also exhibit tolerance to "crowding stress", which is essential for fully exploiting yield per unit area. Plant density in farmer's field is considered a very important stress factor, since competition between different plant species or between different maize hybrids is very strong [3]. Modern hybrids have the same yielding potential as older ones when grown under nonstress conditions [1]. However, it is clear that modern hybrids have embedded stress tolerance especially in plant density stress [4], as well as other biotic and abiotic factors [5]. As a result of the previous statements, increasing plant density in maize cultivations lead to increased field yield until an optimum is reached [6]. Larson and Hanway [7] reported different plant densities in order to achieve maximum yields in maize, including field yield. They also reported that increasing plant density up to 70,000 or even 100,000 plants per hectare may result in optimum performance. Factors significantly affecting maize field yield are population density of plants, as well as row spacing [8]. Row spacing significantly affects the equal distribution of plants and assigns overall population density. The plants compete for nutrients, light and other growth factors. It is assumed that plants equally spaced will give the minimum competition and maximum performance for each provisionally assigned plant density $[8,9]$. Decreasing row spacing reduces soil heterogeneity [9] and also leads plant-to-plant competition in the way of better exploitation of unit area, when concerning the same monogenotypic variety in a certain field [10]. Furthermore, row spacing influences canopy architecture and the type of inputs exploitation (along with photosphere and rhizosphere exploitation) by the plants [11]. After all, inputs exploitation seems to be one of the most important parameters for maximizing field yield [12]. On the other hand, when concerning improvement of single plant yield potential, it seems that absence of density stress is very important for increasing efficiency [12]. An alternative system of narrowing plant rows is the twin row system, which can maintain some benefits of space [13]. In other crops, this cultivation technique of twin rows turned into common practice [14].

Concerning relations between maize characteristics, literature is rather poor. Specific or test weight was found negatively correlated to plant height, ear height, yield, leaf area index (LAI), and 1000-kernel weight [15]. Other researchers mentioned the positive relation between yield and some other traits, excluding plant height [16]. Stress conditions may distort significantly correlations [17].

The objective of this study was to evaluate the effect of population density and row spacing on field yield and other morphological characteristics of two commercial F1 maize hybrids, in relation to the different environmental conditions across the four years of experimentation.

\section{Materials and Methods}

Field experiments were conducted in 2009, 2010, 2011, and 2012 in the Technological Education Institute farm of Florina, Greece ( $40^{\circ} 46^{\prime} \mathrm{N}, 21^{\circ} 22^{\prime} \mathrm{E}, 705 \mathrm{~m}$ a.s.l.). The soil type was Sandy Loam (SL): Sand $61.2 \%$, Silt $27.6 \%$, Clay $11.2 \%$ with pH 6.25 , and organic matter content $1.29 \%$. Environmental data (mean monthly temperatures in ${ }^{\circ} \mathrm{C}$ and rainfall in $\mathrm{mm}$ ) based on daily records are presented in Figure 1.

The experimental design was a split-split plot with four replications. Main plots were the row spacing, subplot was maize hybrids, and sub-subplot was plant density. The plots consisted of (a) single rows with $75 \mathrm{~cm}$ row-to-row spacing, (b) single rows with $50 \mathrm{~cm}$ row-to-row spacing, and (c) twin rows distanced $25 \mathrm{~cm}$ to each other, with $50 \mathrm{~cm}$ row-to-row spacing between the sets of twin rows. Two maize hybrids differing in relative maturity (biological cycle-maturity class) were sown, LG 3535 (FAO 500) and COSTANZA (FAO 660). Two plant densities (75,000 and 112,500 plants/ha) were used in each season. Plot sizes were: (a) $3 \mathrm{~m} \times 5 \mathrm{~m}=15 \mathrm{~m}^{2}$ and consisted of four rows of maize in $75 \mathrm{~cm}$ row spacing, (b) six rows of maize in $50 \mathrm{~cm}$ row spacing, and (c) four twin rows.

Maize seed were sown on 14 May 2009, 7 May 2010, 6 May 2011 and 11 May 2012. The maize hybrids were over-seeded at a double rate and then thinned by hand at the two-leaf stage to achieve the desired plant densities. Nitrogen and P fertilizer (element level) were applied at the same rate of 150 and $75 \mathrm{~kg} / \mathrm{ha}$, respectively, at the sowing dates, while additional N (135 kg/ha) was applied 
when the plants reached $50 \mathrm{~cm}$ in height (boot stage). Weed control was ensured using post-emergence herbicides. Irrigation was conducted regularly (usually within a 10-day interval) in order to avoid any water stress level at any growth stage. The experiments were harvested on 25 November 2009, 17 December 2010, 15 December 2011 and 30 October 2012.

Ten plants were selected randomly from each plot at harvest and plant height (in $\mathrm{cm}$ ), ear emergence height (in $\mathrm{cm}$ ), ear length (in $\mathrm{cm}$ ), ear diameter (in $\mathrm{mm}$ ), number of grain rows per ear, grains number per ear, grain weight per ear (in g), spindle weight per ear (in g), and spindle diameter (in $\mathrm{mm}$ ) were measured. Also, grain yield of each plot (in g) was measured and field yield in $\mathrm{kg} / \mathrm{ha}$, thousand kernel weight (in g), and weight per liter-bulk density (in g/L) were calculated. Analysis of variance (ANOVA) was performed by SPSS ver. 17, involving all the following factors: Row spacing, hybrid and plant density as fixed effects, year effect (analysis across years), and their interactions with replications as random effects, based on Steel et al. [18]. Means were compared using Duncan Test at $p<0.05$. Pearson correlations between all characteristics were also performed. AMMI (GGE) Biplot analysis for interactions were retrieved using the free version of PB Tools, mainly for yield and with most significant factors.

2009

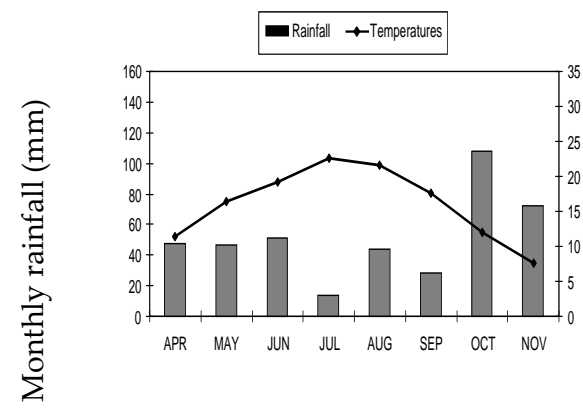

2011

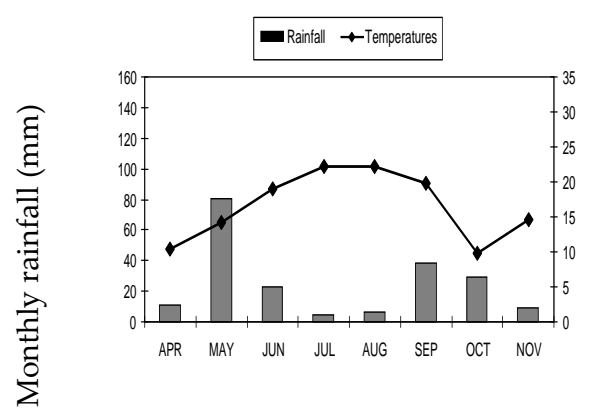

2010
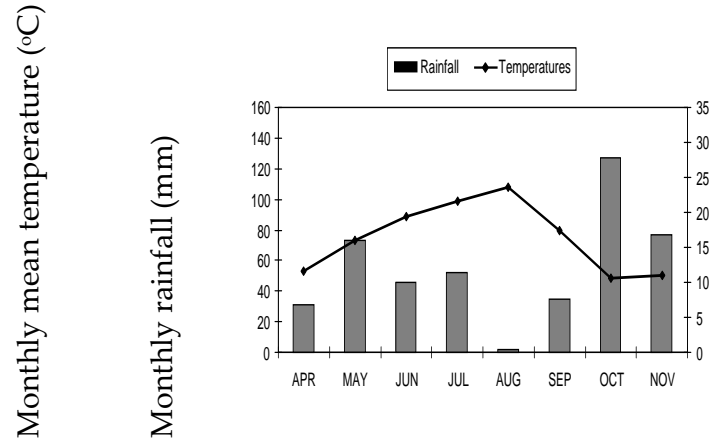

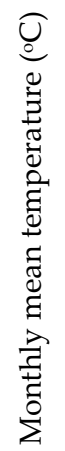

2012

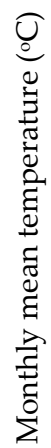

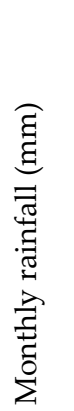

Figure 1. Basic weather data (mean monthly temperature in ${ }^{\circ} \mathrm{C}$ and rainfall in $\mathrm{mm}$ ) based on daily records, for years 2009-2012.

\section{Results and Discussion}

In modern maize hybrids, field yield increases with plant density until a maximum population is reached, according to the growing environment and after this maximum field yield declines [6].

Tables 1 and 2 summarize our findings on field yield, thousand kernel weight, weight per liter (bulk density), number of grain rows per ear, grains number per ear, ear length, ear diameter, spindle weight per ear, spindle diameter, plant height, and ear height emergence, as well as analysis of 
variance for the twelve agronomic characteristics across all factors (year, row spacing, hybrid and plant population).

Table 1. Means of each characteristic per factor for: Field yield in $\mathrm{kg} / \mathrm{ha}$, thousand kernel weight (in $\mathrm{g}$ ), weight per liter-bulk density (in $\mathrm{g} / \mathrm{L}$ ), grains weight per ear, number of grain rows per ear, grains number per ear, ear length (in $\mathrm{mm}$ ), ear diameter (in $\mathrm{mm}$ ), spindle weight per ear (in $\mathrm{g}$ ), spindle diameter (in $\mathrm{mm}$ ), plant height (in $\mathrm{cm}$ ), ear emergence height (in $\mathrm{cm}$ ), across all factors (year, row spacing, hybrid and plant population).

\begin{tabular}{|c|c|c|c|c|c|c|}
\hline Characteristic per Factor & $\begin{array}{l}\text { Field } \\
\text { Yield }\end{array}$ & $\begin{array}{c}\text { Thousand } \\
\text { Kernel } \\
\text { Weight }\end{array}$ & $\begin{array}{l}\text { Weight per } \\
\text { Litre (Bulk } \\
\text { Density) }\end{array}$ & $\begin{array}{l}\text { Grains } \\
\text { Weight } \\
\text { per Ear }\end{array}$ & $\begin{array}{c}\text { Number of } \\
\text { Grain Rows } \\
\text { per Ear }\end{array}$ & $\begin{array}{c}\text { Grains } \\
\text { Number per } \\
\text { Ear }\end{array}$ \\
\hline \multicolumn{7}{|l|}{ Treatment factors } \\
\hline \multicolumn{7}{|l|}{ Year } \\
\hline 2009 & $17,042 \mathrm{a}$ & $398 \mathrm{a}$ & $619 \mathrm{~d}$ & $200 c$ & $15.8 \mathrm{a}$ & 595 a \\
\hline 2010 & $15,888 \mathrm{~b}$ & $374 b$ & $636 c$ & $216 \mathrm{~b}$ & $15.6 \mathrm{ab}$ & $610 \mathrm{a}$ \\
\hline 2011 & $9572 \mathrm{~b}$ & $304 \mathrm{~d}$ & $663 \mathrm{~b}$ & $157 \mathrm{~d}$ & $15.3 \mathrm{~b}$ & $517 b$ \\
\hline 2012 & $14,352 \mathrm{c}$ & $350 \mathrm{c}$ & 709 a & 233 a & $15.7 \mathrm{ab}$ & $610 \mathrm{a}$ \\
\hline \multicolumn{7}{|l|}{ Row spacing } \\
\hline $75 \mathrm{~cm}$ & $13,701 \mathrm{~b}$ & $357 \mathrm{~b}$ & 657 & $203 \mathrm{a}$ & 15.5 & 585 \\
\hline Twin rows & $14,167 \mathrm{~b}$ & $344 \mathrm{c}$ & 658 & $192 b$ & 15.6 & 590 \\
\hline $50 \mathrm{~cm}$ & $14,772 \mathrm{a}$ & 369 a & 656 & $210 \mathrm{a}$ & 15.6 & 573 \\
\hline \multicolumn{7}{|l|}{ Hybrid } \\
\hline LG 3535 & 14,063 & 344 & 657 & 192 & 15.3 & 576 \\
\hline COSTANZA & 14,364 & 369 & 656 & 211 & 15.9 & 589 \\
\hline \multicolumn{7}{|l|}{ Plant density (Plant/ha) } \\
\hline 75000 & 13,900 & 364 & 656 & 213 & 15.6 & 601 \\
\hline 112500 & 14,527 & 350 & 657 & 190 & 15.6 & 565 \\
\hline Characteristic per Factor & $\begin{array}{c}\text { Ear } \\
\text { Length }\end{array}$ & $\begin{array}{c}\text { Ear } \\
\text { Diameter }\end{array}$ & $\begin{array}{c}\text { Spindle } \\
\text { Weight per } \\
\text { Ear }\end{array}$ & $\begin{array}{l}\text { Spindle } \\
\text { Diameter }\end{array}$ & $\begin{array}{l}\text { Plant } \\
\text { Height }\end{array}$ & $\begin{array}{c}\text { Ear } \\
\text { Emergence } \\
\text { Height }\end{array}$ \\
\hline \multicolumn{7}{|l|}{ Treatment factors } \\
\hline \multicolumn{7}{|l|}{ Year } \\
\hline 2009 & $19.3 \mathrm{a}$ & $51.7 \mathrm{a}$ & $46.99 \mathrm{a}$ & $27.5 \mathrm{a}$ & $335 \mathrm{a}$ & 133 \\
\hline 2010 & $18.9 \mathrm{~b}$ & $48.9 \mathrm{~b}$ & $40.72 \mathrm{~b}$ & $25.3 \mathrm{~b}$ & $320 \mathrm{~b}$ & 134 \\
\hline 2011 & $17.8 \mathrm{~d}$ & $44.2 \mathrm{~d}$ & $23.23 \mathrm{~d}$ & $23.4 \mathrm{c}$ & $308 c$ & 132 \\
\hline 2012 & $18.5 \mathrm{c}$ & $46.2 \mathrm{c}$ & $36.12 \mathrm{c}$ & $20.1 \mathrm{~d}$ & $305 c$ & 134 \\
\hline \multicolumn{7}{|l|}{ Row spacing } \\
\hline $75 \mathrm{~cm}$ & $18.5 \mathrm{~b}$ & $47.6 \mathrm{ab}$ & $36.67 \mathrm{ab}$ & 24.3 & $312 \mathrm{~b}$ & $110 \mathrm{c}$ \\
\hline Twin rows & $18.3 \mathrm{~b}$ & $47.3 \mathrm{~b}$ & $35.28 \mathrm{~b}$ & 23.9 & 318 a & $140 \mathrm{~b}$ \\
\hline $50 \mathrm{~cm}$ & $19.1 \mathrm{a}$ & $48.3 \mathrm{a}$ & $38.34 \mathrm{a}$ & 24.1 & $320 \mathrm{a}$ & $149 \mathrm{a}$ \\
\hline \multicolumn{7}{|l|}{ Hybrid } \\
\hline LG 3535 & 17.8 & 46.9 & 31.93 & 23.3 & 317 & 133 \\
\hline COSTANZA & 19.3 & 48.6 & 41.60 & 24.9 & 316 & 133 \\
\hline \multicolumn{7}{|l|}{ Plant density (Plant/ha) } \\
\hline 75,000 & 19.1 & 48.3 & 37.39 & 24.3 & 317 & 133 \\
\hline 112,500 & 18.1 & 47.2 & 36.14 & 23.9 & 316 & 133 \\
\hline
\end{tabular}

The same letters or no letters mean lack of significant differences at $p \leq 0.05$. 
Table 2. Analysis of variance for the 12 agronomic characteristics across all factors (year, row spacing, hybrid and plant population), including degrees of freedom (df), significance level, error, and Coefficient of variation $(\mathrm{CV} \%)$.

\begin{tabular}{|c|c|c|c|c|c|c|c|}
\hline Characteristic per Factor & & $\begin{array}{l}\text { Field } \\
\text { Yield }\end{array}$ & $\begin{array}{c}\text { Thousand } \\
\text { Kernel } \\
\text { Weight }\end{array}$ & $\begin{array}{c}\text { Weight per } \\
\text { Litre (Bulk } \\
\text { Density) }\end{array}$ & $\begin{array}{l}\text { Grains } \\
\text { Weight } \\
\text { per Ear }\end{array}$ & $\begin{array}{c}\text { Number of } \\
\text { Grain Rows } \\
\text { per Ear }\end{array}$ & $\begin{array}{l}\text { Grains } \\
\text { Number } \\
\text { per Ear }\end{array}$ \\
\hline Source of variation & $\mathrm{df}$ & & & & & & \\
\hline Year $(\mathrm{Y})$ & 3 & $* * * *$ & $* * *$ & $* * *$ & $* * *$ & * & **** \\
\hline Replication (Y) & 12 & $* * *$ & ns & ns & ns & ns & $\mathrm{ns}$ \\
\hline Row spacing $(\mathrm{R})$ & 2 & $* * *$ & $* * *$ & ns & $* *$ & ns & $*$ \\
\hline $\mathrm{Y} \times \mathrm{R}$ & 6 & $* * *$ & $* * *$ & $* * *$ & $* *$ & * & ns \\
\hline $\operatorname{Rep}(Y) \times R$ & 24 & ns & ns & $*$ & ns & ns & ns \\
\hline Hybrid (H) & 1 & ns & $* * *$ & ns & $* * *$ & $* * *$ & ns \\
\hline $\mathrm{Y} \times \mathrm{H}$ & 3 & $* *$ & $* * *$ & ns & ns & $\mathrm{ns}$ & ns \\
\hline $\mathrm{R} \times \mathrm{H}$ & 2 & ns & $* * *$ & ns & ns & ns & ns \\
\hline $\mathrm{Y} \times \mathrm{R} \times \mathrm{H}$ & 6 & ns & ns & ns & ns & ns & ns \\
\hline Plant density $(\mathrm{P})$ & 1 & $* *$ & $* *$ & ns & $* * *$ & ns & $* * *$ \\
\hline $\mathrm{Y} \times \mathrm{P}$ & 3 & ns & ns & ns & ns & ns & ns \\
\hline $\mathrm{R} \times \mathrm{P}$ & 2 & ns & $* *$ & ns & ns & ns & ns \\
\hline $\mathrm{Y} \times \mathrm{R} \times \mathrm{P}$ & 6 & ns & ns & ns & ns & ns & ns \\
\hline $\mathrm{H} \times \mathrm{P}$ & 1 & ns & ns & ns & ns & ns & ns \\
\hline $\mathrm{Y} \times \mathrm{H} \times \mathrm{P}$ & 3 & ns & ns & ns & ns & ns & ns \\
\hline $\mathrm{R} \times \mathrm{H} \times \mathrm{P}$ & 2 & * & ns & ns & $\mathrm{ns}$ & $\mathrm{ns}$ & $\mathrm{ns}$ \\
\hline $\mathrm{Y} \times \mathrm{R} \times \mathrm{H} \times \mathrm{P}$ & 6 & ns & ns & ns & ns & ns & ns \\
\hline Poled error & 108 & & & & & & \\
\hline $\mathrm{CV} \%$ & & 9.3 & 9.0 & 4.3 & 14.0 & 4.6 & 11.2 \\
\hline Characteristic per Factor & & $\begin{array}{c}\text { Ear } \\
\text { Length }\end{array}$ & $\begin{array}{c}\text { Ear } \\
\text { Diameter }\end{array}$ & $\begin{array}{c}\text { Spindle } \\
\text { Weightper } \\
\text { Ear }\end{array}$ & $\begin{array}{l}\text { Spindle } \\
\text { Diameter }\end{array}$ & $\begin{array}{l}\text { Plant } \\
\text { Height }\end{array}$ & $\begin{array}{c}\text { Ear } \\
\text { Emergence } \\
\text { Height }\end{array}$ \\
\hline Source of variation & $\mathrm{df}$ & & & & & & \\
\hline Year $(\mathrm{Y})$ & 3 & $* * *$ & $* * *$ & $* * *$ & $* * *$ & $* * *$ & ns \\
\hline Replication (Y) & 12 & ns & ns & ns & ns & ns & $\mathrm{ns}$ \\
\hline Row spacing $(\mathrm{R})$ & 2 & $* * *$ & $*$ & $*$ & ns & $* * *$ & **** \\
\hline $\mathrm{Y} \times \mathrm{R}$ & 6 & $*$ & * & ns & ns & ns & ns \\
\hline $\operatorname{Rep}(\mathrm{Y}) \times \mathrm{R}$ & 24 & ns & ns & ns & ns & ns & ns \\
\hline Hybrid $(\mathrm{H})$ & 1 & $* * *$ & $* * *$ & $* * *$ & $* * *$ & ns & ns \\
\hline $\mathrm{Y} \times \mathrm{H}$ & 3 & ns & $* * *$ & $* * *$ & ns & ns & ns \\
\hline $\mathrm{R} \times \mathrm{H}$ & 2 & ns & ns & ns & ns & ns & ns \\
\hline $\mathrm{Y} \times \mathrm{R} \times \mathrm{H}$ & 6 & ns & ns & ns & ns & ns & ns \\
\hline Plant density $(\mathrm{P})$ & 1 & $* * *$ & $* * *$ & ns & * & $\mathrm{ns}$ & $\mathrm{ns}$ \\
\hline $\mathrm{Y} \times \mathrm{P}$ & 3 & ns & ns & $*$ & ns & ns & ns \\
\hline $\mathrm{R} \times \mathrm{P}$ & 2 & ns & ns & ns & $* * *$ & ns & $*$ \\
\hline $\mathrm{Y} \times \mathrm{R} \times \mathrm{P}$ & 6 & $*$ & ns & ns & $* *$ & ns & ns \\
\hline $\mathrm{H} \times \mathrm{P}$ & 1 & ns & ns & ns & $*$ & ns & ns \\
\hline $\mathrm{Y} \times \mathrm{H} \times \mathrm{P}$ & 3 & $\mathrm{~ns}$ & ns & ns & $\mathrm{ns}$ & ns & $\mathrm{ns}$ \\
\hline $\mathrm{R} \times \mathrm{H} \times \mathrm{P}$ & 2 & ns & ns & $* * *$ & $*$ & $\mathrm{~ns}$ & ns \\
\hline $\mathrm{Y} \times \mathrm{R} \times \mathrm{H} \times \mathrm{P}$ & 6 & ns & ns & $*$ & ns & ns & ns \\
\hline Poled error & 108 & & & & & & \\
\hline $\mathrm{CV} \%$ & & 5.9 & 3.8 & 18.8 & 5.0 & 2.8 & 4.7 \\
\hline
\end{tabular}

F-probability values: ${ }^{*} p \leq 0.05 ;{ }^{* *} p \leq 0.01 ;{ }^{* * *} p \leq 0.001 ;$ ns $=$ not significant.

\subsection{Yield Estimations and Factor Effects}

Concerning field yield of the two hybrids (Table 1), ANOVA showed statistically significant differences for the four years of experimentation (Table 2), indicating strong interaction of the genotypes with different environmental conditions across years (Figure 2). In Figure 2, genotypes were also separated for yield favoring years (for each hybrid) by AMMI Biplot analysis. Differences between hybrids were not significant, although Costanza exhibited greater mean field yield performance $(14,364 \mathrm{~kg} / \mathrm{ha})$ in comparison to LG3535 (14,063 kg/ha). Plant density was a significant factor [3] and yield increased from low to high plant population (from 13,900 to 14,527 kg/ha), but unfortunately, it cannot be separated effectively in principle components. Ipsilandis and Vafias [6] showed that modern 
hybrids increase their field yield as plant density increases up to a certain limit $(>100,000$ plants per Ha). Row spacing had a significant interaction with year and the same was evident for hybrid behavior (different yields) across years. Greveniotis et al. [19] showed that maize hybrids of middle to high maturity class (FAO $>500$ and $<700$ ) have almost the same yielding performance (per area unit), which is greater than hybrids of very high maturity class $(\mathrm{FAO}>700)$ or very low maturity class $(\mathrm{FAO}<500)$ because of the limits of the growing period.

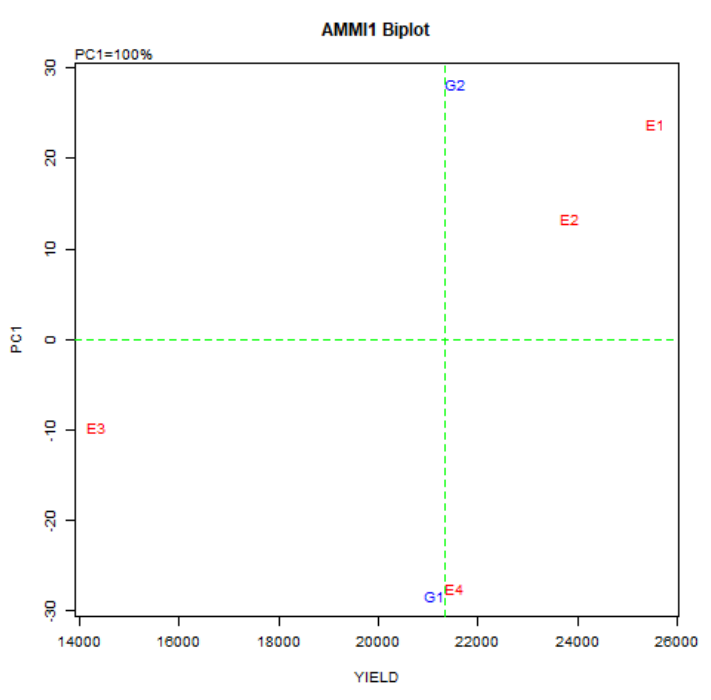

(a)

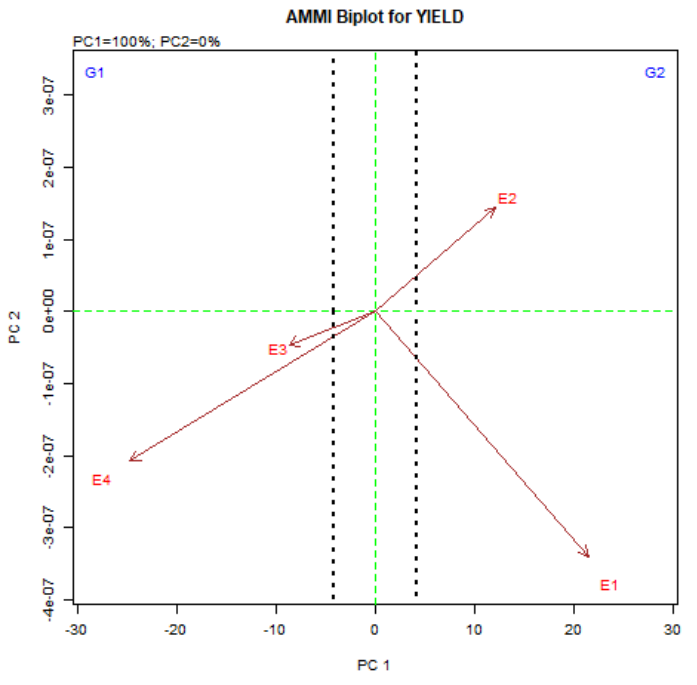

(b)

Figure 2. AMMI Biplot for genotypes $(\mathrm{G})$ and years (E) for yield and separation of genotypes for yield favoring years. (a) The contribution on variance of the factor of years in the treatment of yield (E) the year E2 and E3 gives a small amount on variance whereas E1 and E4 are the most diverse years producing variance over the genotypes G1 and G2 for the variable of yield. (b) The deviation of years from the ideal year, E3 has the smaller deviation of the ideal year on yield; the favorable years for G1 are the E3 and E4 whereas the favorable years for G2 are the E1 and E2.

Significant interaction was found between row spacing, plant density, and genotypes (maize hybrids), as shown in Table 2. Robles et al. [20] reported that although there were differences between different genotypes, interaction did not occur. Novacek et al. [21] reported statistically significant differences between hybrids, but interaction between year, population, and row configuration was also present. Our data suggest that increased population stand tends to increase hybrid yielding performance, but not at the same level for all hybrids [6] without being able to separate effectively factors in principle components. Some hybrids perform better in high populations [9], and this was very clear for both the hybrids used, while row configuration in the most dense spacing $(50 \mathrm{~cm})$ had also the same impact in our data set and both hybrids were favored for almost all characteristics (including yield). Year proved to be the most important factor, because significant differences were present in almost all cases, except of ear emergence height, which seems to be depended on crop stand (plant population). Novacek et al. [21] also showed that there are differences between years in yielding performance of genotypes, and Robles et al. [20] attributed these differences in year-to-year differentiation of environmental conditions, which were also apparent in our results. Tang et al. [22] stated that normalization of density-yield model may remove Genotype $x$ Environment over year interactions for more secure yield estimations, but in our case, the factor interactions were more complex.

\subsection{Thousand Kernel Weight, Bulk Density and Factor Effects}

Concerning thousand kernel weight, differences between hybrids were significant (ranging from 344 to $369 \mathrm{~g}$ ), as shown also by Testa et al. [23]. Plant density was a significant factor and thousand 
kernel weight showed the highest value at low plant density (364 g). Row spacing had an extremely significant interaction with year, and the same was clear for hybrid behavior across years and in relation to row spacing, indicating different behavior of genotypes in different environmental conditions. A significant interaction was also found between row spacing and plant density, indicating that row spacing may favor yielding performance within a reasonable plant density limit [6]. These findings are in agreement with Novacek et al. [21]. For bulk density, ANOVA showed that statistically significant differences were present for the four years of experimentation. Row spacing had a significant interaction with year (year 2012 was the most favorable, $709 \mathrm{~g} / \mathrm{L}$ ). Differences between hybrids were significant. Hybrid Costanza showed the highest values (211 g). Novacek et al. [21] showed significant differences only between hybrids and row spacing. It is obvious that the goal of density-independent hybrids, free of environmental and year effects for yield characteristics, was not achieved for the certain genetic materials used in our study [12].

\subsection{Number of Grain Rows, Grains Number per Ear, Grains Weight, and Factor Effects}

For number of grain rows per ear, ANOVA showed that statistically significant differences were present for the four years of experimentation. Row spacing had a significant interaction with year indicating different behavior of genotypes in different environmental conditions. Differences between hybrids were significant (Costanza reached 16 rows of grains). Testa et al. [23] also found statistical differences between hybrids, and this trait seems to be dependent on the genotypes. For grain number per ear, ANOVA showed that statistically significant differences were present for the four years of experimentation. Row spacing and plant density showed also significant differences. Twin rows showed the highest values (590 grains) and the same was found for low density (601 grains). Haegele et al. [24] reported a kind of interaction between these factors number of grains. In our paper, grain number declined as plant population increased, and this is in agreement with the findings of Zhang et al. [25]. Also, row spacing had a significant interaction with year for grains weight per ear, accompanied by hybrid differences and plant density effects.

\subsection{Ear Characteristics and Factor Effects}

For ear length, ANOVA showed that statistically significant differences were present for the four years of experimentation. Hybrids, row spacing, and plant density also showed significant differences (hybrid Costanza reached $19.3 \mathrm{~cm}$ ). Significant interaction was found between years, plant density, and row spacing. Similar results have been presented by Bavec and Bavec [26]. For ear diameter, ANOVA showed that statistically significant differences were present for the four years of experimentation. Plant density also showed significant differences for ear diameter. Low plant populations favored this trait $(48.3 \mathrm{~mm})$. Interactions were found between row spacing and years and also for row spacing and hybrids. Genotypes affect ear diameter according to many researchers and in some cases year, while plant population and row spacing have been reported without significant differences [26,27]. In our dataset, row spacing may affect ear diameter, but this depends on the environmental conditions of different years and genotypes used. Generally, lower populations and higher FAO hybrid exhibited greater ear diameter. Ear characteristics showed an unstable behavior depending on year, environmental and field design effects.

\subsection{Spindle Characteristics and Factor Effects}

For spindle weight per ear, a total interaction between years (maximum in 2009, $46.99 \mathrm{~g}$ ), row spacing, hybrids, and plant density was found, which is important for the part of row spacing, hybrids, and plant density, indicating a different behavior of genotypes in different plant populations, environmental conditions, and row architecture. For spindle diameter, various significant interactions were found, including years (maximum also in 2009, $27.5 \mathrm{~mm}$ ), row spacing, and plant density and also row spacing, hybrids, and plant density. Maize genotypes and plant density have been reported for affecting spindle diameter with the intimation that environmental conditions may modify 
these effects [27]. Genotype and year interactions have been also reported as main factor effects by Gozubenli [28], who also suggested that twin rows may affect positively spindle diameter in comparison to single ones. Generally, our data suggest that spindle characteristics are affected by combinations of various factors, being rather unstable characteristics across years and field designs.

\subsection{Height Characteristics and Factor Effects}

For plant height, ANOVA showed that statistically significant differences were present for the factor's years of experimentation and for row spacing. Twin and narrow rows favored plant height, which reached $320 \mathrm{~cm}$. Turgut et al. [29] reported that plant height is a genetic phenomenon depending on the genotypes used. Row configuration, plant density, and hybrids have been reported as the most significant factors by Novacek et al. [21]. For ear emergence height, ANOVA showed no significant differences for years. Row spacing differences were significant, and interaction was found between row spacing and plant density. Again, twin and narrow rows favored ear height which reached $149 \mathrm{~cm}$. Novacek et al. [21] reported that year may distort row spacing and plant density effects, while our findings showed that year have no impact on this trait. Plant density in accordance to row configuration, are the only combined factors that may affect ear height. Generally, height characteristics (plant and ear emergence) seem to be strongly affected by row configuration. In case of height characteristics, the combination of density and field design was the most important factor.

\subsection{Correlations between Characteristics}

Correlations in Table 3 showed that there were statistically significant relationships between many characteristics. Yield was significantly correlated $\left(r>0.6\right.$ and $\left.r^{2}>0.36\right)$ to thousand kernel weight $(r=0.647)$, spindle weight per ear $(r=0.660)$, and ear diameter $(r=0.707)$, as well as (lower coefficient correlations) to all other characteristics, showing also a negative correlation to bulk (test or specific) weight. Bulk weight showed low correlation coefficients, except to spindle diameter, which was found to be high. Thousand kernel weight was correlated $\left(r>0.6\right.$ and $\left.r^{2}>0.36\right)$ significantly to yield, spindle (and ear) weight, and spindle diameter. Ear diameter showed high correlation coefficients to most of the other characteristics.

In a recent research, height of spike emergence was positively correlated to plant height [30]. They also reported positive correlation between number of grains per row and number of cobs per plant, as well as total number of cobs and final plant stand. Maize final plant stands and thousand kernel weight were reported as considerable parameters for final field yield. Our findings were generally in agreement with the research of Bodi [15] for thousand kernel weight, specific weight, and plant height. Many of these relations could help plant breeders for improvement of yield components. 
Table 3. Correlations between all characteristics (field yield, thousand kernel weight, weight per liter-bulk density, grains weight per ear, number of grain rows per ear, grains number per ear, ear length, ear diameter, spindle weight per ear, spindle diameter, plant height, ear emergence height).

\begin{tabular}{|c|c|c|c|c|c|c|c|c|c|c|c|}
\hline & Field Yield & $\begin{array}{c}\text { Thousand } \\
\text { Kernel } \\
\text { Weight }\end{array}$ & $\begin{array}{c}\text { Weight Per } \\
\text { Litre (Bulk } \\
\text { Density) }\end{array}$ & $\begin{array}{l}\text { Grains } \\
\text { Weight per } \\
\text { Ear }\end{array}$ & $\begin{array}{c}\text { Number } \\
\text { of Grain } \\
\text { Rows } \\
\text { per Ear }\end{array}$ & $\begin{array}{l}\text { Grains } \\
\text { Number } \\
\text { per Ear }\end{array}$ & $\begin{array}{c}\text { Ear } \\
\text { Length }\end{array}$ & $\begin{array}{c}\text { Ear } \\
\text { Diameter }\end{array}$ & $\begin{array}{c}\text { Spindle } \\
\text { Weight per } \\
\text { Ear }\end{array}$ & $\begin{array}{l}\text { Spindle } \\
\text { Diameter }\end{array}$ & $\begin{array}{l}\text { Plant } \\
\text { Height }\end{array}$ \\
\hline Thousand Kernel Weight & $0.647^{* *}$ & & & & & & & & & & \\
\hline Weight per Litre & $-0.275^{* *}$ & $-0.261^{* *}$ & & & & & & & & & \\
\hline Grains Weight per Ear & $0.497^{* *}$ & $0.571^{* *}$ & 0.139 & & & & & & & & \\
\hline $\begin{array}{l}\text { Number of Grain Rows } \\
\text { per Ear }\end{array}$ & $0.215^{* *}$ & $0.269^{* *}$ & 0.057 & $0.337^{* *}$ & & & & & & & \\
\hline Grains Number per Ear & $0.425^{* *}$ & $0.321 * *$ & -0.004 & 0.670 ** & $0.341^{* *}$ & & & & & & \\
\hline Ear Diameter & $0.707^{* *}$ & $0.772 * *$ & $-0.441^{* *}$ & $0.536^{* *}$ & $0.382 * *$ & $0.450^{* *}$ & $0.636^{* *}$ & & & & \\
\hline Spindle Weight per Ear & $0.660 * *$ & $0.729 * *$ & $-0.282 * *$ & $0.567^{* *}$ & 0.311 ** & $0.494^{* *}$ & $0.626^{* *}$ & $0.732 * *$ & & & \\
\hline Spindle Diameter & $0.384^{* *}$ & $0.503^{* *}$ & $-0.640 * *$ & -0.003 & $0.190^{* *}$ & 0.067 & $0.422 * *$ & 0.672 ** & $0.514^{* *}$ & & \\
\hline Spindle Weight per Ear & $0.544^{* *}$ & 0.462 ** & $-0.516^{* *}$ & 0.130 & 0.125 & $0.187^{* *}$ & $0.347^{* *}$ & $0.646^{* *}$ & $0.461^{* *}$ & $0.666^{* *}$ & \\
\hline Ear Length & $0.175 *$ & 0.031 & -0.003 & 0.066 & 0.038 & -0.023 & 0.122 & 0.062 & 0.009 & -0.048 & $0.237^{* *}$ \\
\hline
\end{tabular}

${ }^{*}$ Correlation is significant at the 0.05 level (two-tailed). ${ }^{* *}$ Correlation is significant at the 0.01 level (two-tailed). 


\section{Conclusions}

Four years of experimentation clarified that environmental conditions may distort all other effects of the factors studied, for the 11 out of 12 characteristics. Row spacing had an extremely significant interaction with year, and the same was clear for hybrid behavior across years and in relation to row spacing, indicating different behavior of genotypes in different environmental conditions. A significant interaction was also found between row spacing and plant density, indicating that row spacing may favor yielding performance within a reasonable plant density limit. In order to fully exploit cultivation area, plants must be properly distributed, and in parallel, the genotype density resistance must be assessed. This study points out the best combinations of plant density (stand) and row configuration. High populations (112,500 plants/ha) and twin or narrow rows $(50 \mathrm{~cm})$ were found to be important for maximizing yield of modern hybrids. Generally, twin or narrow rows favored many characteristics, especially height characteristics (plant height and ear emergence height). Ear diameter was favored by low plant density. Some characteristics (like ear diameter) were depended on the genotype behavior in the certain environmental conditions. From our results it is obvious that the goal of density-independent hybrids, free of environmental and year effects for yield characteristics, was not achieved for the certain genetic materials used. Many correlations were found significant especially between yield and thousand kernel weight, spindle weight per ear, and ear diameter. These relations could help plant breeders for improvement of yield components.

Author Contributions: V.G. designed experiments, collected data, conducted statistical analysis; writing manuscript and editing. S.Z. designed experiments; E.S. conducted statistical analysis, review and editing; C.I., writing - original draft and review.

Funding: This research received no external funding.

Conflicts of Interest: The authors declare no conflict of interest.

\section{References}

1. Duvick, D.N. What is yield? In Developing Drought and Low N-Tolerant Maize. Proceedings of a Symposium. March 25-29, 1996; Edmeades, G.O., Banziger, B., Mickelson, H.R., Pena-Valdivia, C.B., Eds.; CIMMYT: El Batan, Mexico, 1997; pp. 332-335.

2. Duvick, D.N. The contribution of breeding to yield advances in maize (Zea mays L.). Adv. Agron. 2005, 86, 83-145.

3. Tetio-Kagho, F.; Gardner, F.P. Response of maize to plant population density. II. Reproductive development, yield and yield adjustments. Agron. J. 1988, 80, 935-940. [CrossRef]

4. Duvick, D.N. Genetic progress in yield of United States maize (Zea mays L.). Maydica 2005, 50, 193-202.

5. Tollenaar, M.; Wu, J. Yield improvement in temperate maize is attributable to greater stress tolerance. Crop Sci. 1999, 39, 1597-1604. [CrossRef]

6. Ipsilandis, C.G.; Vafias, B.N. Plant density effects on grain yield per plant in maize: Breeding implications. Asian J. Plant Sci. 2005, 4, 31-39.

7. Larson, W.E.; Hanway, J.J. Corn production. In Corn and Corn Improvement; Sprague, G.F., Ed.; American Society of Agronomy, Inc.: Madison, WI, USA, 1977; pp. 625-669.

8. Farnham, D.E. Row spacing, plant density, and hybrid effects on corn grain yield and moisture. Agron. J. 2001, 93, 1049-1053. [CrossRef]

9. Vafias, B.; Goulas, C.; Lolas, G.; Ipsilandis, C.G. A triple stress effect on monogenotypic and multigenotypic maize populations. Asian J. Plant Sci. 2007, 6, 29-35.

10. Barbieri, P.A.; Echeverria, H.E.; Sainz Rozas, H.R.; Andrade, F.H. Nitrogen use efficiency in maize as affected by nitrogen availability and row spacing. Agron. J. 2008, 100, 1094-1100. [CrossRef]

11. Sharratt, B.S.; McWilliams, D.A. Microclimatic and rooting characteristics of narrow-row versus conventional-row corn. Agron. J. 2005, 97, 1129-1135. [CrossRef]

12. Fasoula, D.A.; Fasoula, V.A. Competitive ability and plant breeding. Plant Breed. Rev. 1997, 14, 89-138. 
13. Balkcom, K.S.; Satterwhite, J.L.; Arriaga, F.J.; Price, A.J.; Van Santen, E. Conventional and glyphosate-resistant maize yields across plant densities in single- and twin-row configurations. Field Crop Res. 2011, 120, 330-337. [CrossRef]

14. Johnson, A.W.; Minton, N.A.; Brenneman, T.B.; Burton, G.W.; Culbreath, A.K.; Gascho, G.J.; Baker, S.H.; Johnson, W.C., III. Managing nematodes, fungal diseases, and thrips on peanut with pesticides and crop rotations of bahiagrass, corn, and cotton. Peanut Sci. 1999, 26, 32-39. [CrossRef]

15. Bódi, Z.; Pepó, P.; Kovács, A. Morphology of tassel components and their relationship to some quantitative features in maize. Cereal Res. Commun. 2008, 36, 353-360. [CrossRef]

16. Alaei, Y. Correlation analysis of corn Genotypes morphological traits. Intl. Res. J. Appl. Basic Sci. 2012, 3, 2355-2357.

17. Beiragi, M.A.; Ebrahimi, M.; Mostafavi, K.; Golbashy, M.; Khorasani, S.K. A Study of Morphological Basis of corn (Zea mays L.) yield under drought stress condition using Correlation and Path Coefficient Analysis. J. Cereals Oilseeds. 2011, 2, 32-37.

18. Steel, R.G.D.; Torie, H.; Dickey, D.A. Principles and Procedures of Statistics. A Biometrical Approach, 3nd ed.; McGraw-Hill: New York, NY, USA, 1997.

19. Greveniotis, V.; Xanthopoulou, O.; Pessios, E.; Deligeorgidis, P.; Stefanis, D.; Ipsilandis, C.G. Honeycomb evaluation of barley germplasm under pre-evaluated environments. Cereal Res. Commun. 2009, 37, 579-586. [CrossRef]

20. Robles, M.; Ciampitti, I.A.; Vyn, T.J. Responses of maize hybrids to twin-row spatial arrangement at multiple plant densities. Agron. J. 2012, 104, 1747-1756. [CrossRef]

21. Novacek, M.J.; Mason, S.C.; Galusha, T.D.; Yaseen, M. Twin rows minimally impact irrigated maize yield, morphology, and lodging. Agron. J. 2013, 105, 268-276. [CrossRef]

22. Tang, L.; Ma, W.; Noor, M.A.; Li, L.; Hou, H.; Zhang, X.; Zhao, M. Density resistance evaluation of maize varieties through new "Density-Yield Model" and quantification of varietal response to gradual planting density pressure. Sci. Rep. 2018, 8, 17281. [CrossRef]

23. Testa, G.; Reyneri, A.; Blandino, M. Maize grain yield enhancement through high plant density cultivation with different inter-row and intra-row spacings. Eur. J. Agron. 2016, 72, 28-37. [CrossRef]

24. Haegele, J.W.; Becker, R.J.; Henninger, A.S.; Below, F.E. Row arrangement, phosphorus fertility, and hybrid contributions to managing increased plant density of maize. Agron. J. 2014, 106, 1838-1846. [CrossRef]

25. Zhang, Q.; Zhang, H.; Song, X.; Liu, S.; Jiang, W. Maize yields performance in strip planting patterns with two plant densities. Adv. J. Food Sci. Technol. 2015, 8, 816-823. [CrossRef]

26. Bavec, F.; Bavec, M. Effects of plant population on leaf area index, cob characteristics and grain yield of early maturity maize cultivars (FAO 100-400). Eur. J. Agron. 2002, 16, 151-159. [CrossRef]

27. Sharifi, R.S.; Sedghi, M.; Gholipouri, A. Effect of population density on yield and yield attributes of maize hybrids. Res. J. Biol. Sci. 2009, 4, 375-379.

28. Gozubenli, H. Influence of planting patterns and plant density on the performance of maize hybrids in the eastern Mediterranean conditions. Int. J. Agric. Biol. 2010, 12, 556-560.

29. Turgut, I.; Duman, A.; Bilgili, U.; Acikgoz, E. Alternate row spacing and plant density effects on forage and dry matter yield of corn hybrids (Zea mays L.). J. Agron. Crop. Sci. 2005, 191, 146-151. [CrossRef]

30. Rocha, R.S.; Nascimento, M.R.; Chagas, J.T.B.; de Almeida, R.N.; dos Santos, P.R.; da Cruz, D.P.; da Silva Costa, K.D.; de Amaral Gravina, G.; Daher, R.F. Association among Agro-morphological Traits by Correlations and Path in Selection of Maize Genotypes. J. Exp. Agric. Int. 2019, 34, 1-12.

(C) 2019 by the authors. Licensee MDPI, Basel, Switzerland. This article is an open access article distributed under the terms and conditions of the Creative Commons Attribution (CC BY) license (http://creativecommons.org/licenses/by/4.0/). 